\title{
Experimental Study on Strength and Durability Properties of Steel Fibers \& Glass Fibers using GGBS based Concrete
}

\author{
Roopa Bhargavi P. ${ }^{1}$, Bhanu Pravallika S. ${ }^{2}$ \\ ${ }^{1}$ P.G Student of Structural Engineering, Gudlavalleru Engineering College, Gudlavalleru, Andhra Pradesh, India \\ ${ }^{2}$ Assistant Professor, department of Civil Engineering, Gudlavalleru Engineering College, Gudlavalleru, Andhra Pradesh, India
}

\begin{abstract}
Concrete is the widely used construction material in civil engineering industry due to its massive properties like high structural strength and stability. The demand and cost of cement is growing day to day, so investigators are looking for supplementary materials with the main objective of reducing solid waste disposal problem, by using waste as supplementary by maintaining the same properties or by enhancing the properties by using selected materials. The study has been made to evaluate the effect on mechanical and durability properties of M25 grade concrete made with replacement of cement with Ground Granulate Blast Furnace Slag (GGBS), (0\%, $10 \%, 20 \%, 30 \%$ and $40 \%)$ by weight and the addition of Steel fiber in different percentages $(0 \%, 0.5 \%, 1 \%$, 1.5\% and $2 \%)$ and glass fiber in different percentages $(0 \%, 0.1 \%, 0.2 \%, 0.3 \%, 0.4 \%)$. For each set of fibers, mechanical properties were studied by performing Compression test for Cubes, Flexural test for beams and Split Tensile test for cylinders and durability properties were studied by performing sulphate attack test cubes.
\end{abstract}

Keywords: Concrete, Ground Granulated Blast Furnace Slag, Steel Fibre, Glass fibre, compressive strength, flexural strength and split tensile strength

\section{Introduction}

Concrete is probably the most extensively used construction material in the world. The main constituent in the conventional concrete is Portland cement. The amount of cement manufacture release approximately equal amount of carbon dioxide into the atmosphere. Cement production is consuming significant amount of natural resources. That has brought pressures to reduce cement consumption by the use of supplementary materials. The incorporation of supplementary cementatious material is Ground granulated blast furnace slag (GGBS) is a new mineral admixture, which improve mainly the mechanical properties of concrete and also reduce the cement consumption by replacing part of cement with these pozzolonic materials. Moreover only limited studies have been carried out in India on the use of slag for the development of high strength concrete with addition of steel fibers. GGBS is a superior material which resists salt corrosion $\&$ chemical reactions.

One method to improve the brittle behaviour of the concrete is the addition of small fibers in concrete with randomly distributed. Such reinforced concrete is called Fibre Reinforced Concrete (FRC). There are different types of fibers that can be used in FRC they are Steel fibers, Glass fibers, Synthetic fibers, Carbon fibres, Nylon fibre. In this study the addition of steel and glass fibers are added to concrete, leads to improvement in cracking and tensile strength.

\section{Materials \& Properties}

\subsection{Cement}

Cement used in this experiment work is ordinary Portland cement of 53- grade available in the local market. The cement should be fresh and of uniform consistency. The specific gravity of the cement is 3.15. All properties of cement are tested by referring IS $12269-1987$.

Table 1: Properties of cement

\begin{tabular}{|c|c|c|}
\hline Sl. No. & Property & Value \\
\hline 1 & Fineness test & $7.4 \%$ \\
\hline 2 & $\begin{array}{c}\text { Setting time } \\
\text { a)initial } \\
\text { b)final }\end{array}$ & $\begin{array}{c}40 \mathrm{~min} \\
270 \mathrm{~min}\end{array}$ \\
\hline 3 & Specific gravity & 3.15 \\
\hline 4 & Soundness test & $4.5 \mathrm{~mm}$ \\
\hline
\end{tabular}

\subsection{Fine aggregates}

Locally available sand conforming to grading zone II which is passing from $4.75 \mathrm{~mm}$ sieve and of specific gravity of 2.63 is used.

Table 2: Properties of fine aggregate

\begin{tabular}{|c|c|c|}
\hline Sl. No. & Property & Value \\
\hline 1 & Sieve analysis & Zone II \\
\hline 2 & Specific gravity & 2.67 \\
\hline
\end{tabular}

\subsection{Coarse aggregate}

Locally available crushed stones conforming to graded aggregate of nominal size $20 \mathrm{~mm}$ as per IS: $383-1970$. Specific gravity of course aggregate is 2.77 .

Table 3: Properties of coarse aggregate

\begin{tabular}{|c|c|c|}
\hline Sl. No. & Property & Value \\
\hline 1 & Crushing value & $14.36 \%$ \\
\hline 2 & Impact value & $2.7 \%$ \\
\hline 3 & Abrasion value & $11 \%$ \\
\hline 4 & Specific gravity & 2.7 \\
\hline 5 & Water absorption & $0.5 \%$ \\
\hline
\end{tabular}

Volume 5 Issue 6, June 2016 www.ijsr.net 


\section{International Journal of Science and Research (IJSR) \\ ISSN (Online): 2319-7064}

Index Copernicus Value (2013): 6.14 | Impact Factor (2015): 6.391

\subsection{Water}

Fresh potable water free from acid and organic substances was used for mixing and curing concrete.

\subsection{Ground granulated blast furnace slag}

GGBS is obtained by quenching molten iron slag (a byproduct of iron and steel making) from a blast furnace in water or steam, to produce a glassy, granular product that is then dried and ground into a fine powder. Specific gravity of GGBS is 2.85 .

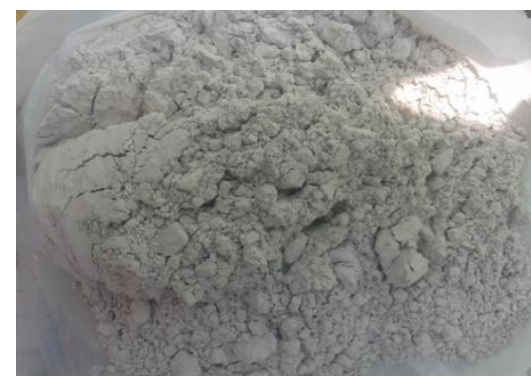

Figure 1: GGBS

\subsubsection{Chemical composition of GGBS}

GGBS comprises mainly of $\mathrm{CaO}, \mathrm{SiO}_{2}, \mathrm{Al}_{2} \mathrm{O}_{3}, \mathrm{MgO}$, it contains less than $1 \%$ crystalline silica, and contains less than $1 \mathrm{ppm}$ water soluble chromium IV. It has the same main chemical constituents as ordinary Portland cement, but in different proportions.

Table 4: Chemical Composition of GGBS

\begin{tabular}{|c|c|c|}
\hline Chemical Constituent & Portland & GGBS \\
\hline $\mathrm{CaO}$ & $65 \%$ & $40 \%$ \\
\hline $\mathrm{SiO}_{2}$ & $20 \%$ & $35 \%$ \\
\hline $\mathrm{AI}_{2} \mathrm{O}_{3}$ & $5 \%$ & $10 \%$ \\
\hline $\mathrm{MgO}$ & $2 \%$ & $8 \%$ \\
\hline
\end{tabular}

Because of these chemical similarities, Ecocem GGBS can be replaced for Portland cement in concrete mixes by as much as up to $95 \%$ (EN 197-1 allows for up to $95 \%$ replacement).

\subsubsection{Physical properties of GGBS}

Table 5: Physical Properties of GGBS

\begin{tabular}{|l|l|}
\hline Colour & Off-white powder \\
\hline Bulk density (loose) & $1.0-1.1$ tonnes $/ \mathrm{m}^{3}$ \\
\hline Bulk density (vibrated) & $1.2-1.3$ tonnes $/ \mathrm{m}^{3}$ \\
\hline Relative density & $2.85-2.95$ \\
\hline Surface area & $400-600 \mathrm{~m}^{2} / \mathrm{kg}$ Blaine \\
\hline
\end{tabular}

\subsection{Steel Fiber}

Fiber is a small piece of reinforcing material possessing certain characteristics properties. They can be circular or flat. The fiber is often described by a convenient parameter called "aspect ratio". The steel fiber type used here is hooked end with $35 \mathrm{~mm}$ fiber length and $0.45 \mathrm{~mm}$ diameter. The aspect ratio of the fiber is the ratio of its length to its diameter and generally the aspect ratio ranges from 30 to 150 and here the aspect ratio of the steel fiber is 80 .

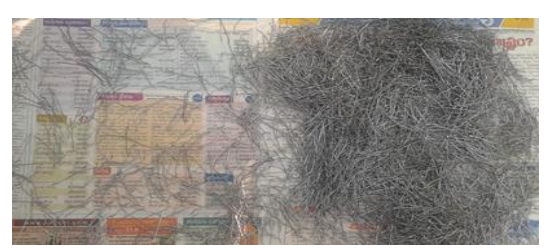

Figure 2: Steel fibre

The following value gives the effects of fibers on concrete

Table 6: Properties of steel fiber

\begin{tabular}{|c|c|}
\hline Properties & $\begin{array}{c}\text { Improvement Over } \\
\text { Ordinary Concrete }\end{array}$ \\
\hline Ductility & 5 to 10 times \\
\hline Impact resistance & 100 to $200 \%$ \\
\hline Cracking \& flexural strength & 80 to $120 \%$ \\
\hline Shear strength & 50 to $100 \%$ \\
\hline Bearing strength & 50 to $100 \%$ \\
\hline Abrasion resistance & several times \\
\hline
\end{tabular}

\subsection{Glass fiber}

It is material made from extremely fine fibers of glass Fiberglass is a lightweight, extremely strong, and robust material. The glass fiber type used here is E glass with $50 \mathrm{~mm}$ fiber length and $0.1 \mathrm{~mm}$ diameter. The aspect ratio of the glass fiber is 500 .

\subsubsection{Composition of glass fiber}

E-CR-glass (Electrical/Chemical Resistance; alumino-lime silicate with less than $1 \%$ w/w alkali oxides, with high acid resistance). E-glass ("E" because of initial electrical application), is alkali free, and was the first glass formulation used for continuous filament formation. It now makes up most of the fibreglass production in the world, and also is the single largest consumer of boron minerals globally. It is susceptible to chloride ion attack and is a poor choice for marine applications.

Table 7: Properties of glass fiber

\begin{tabular}{|l|c|c|c|c|c|}
\hline $\begin{array}{c}\text { Fiber } \\
\text { type }\end{array}$ & $\begin{array}{c}\text { Tensile } \\
\text { strength } \\
(\mathrm{MPa})\end{array}$ & $\begin{array}{c}\text { Comp. } \\
\text { strength } \\
(\mathrm{MPa})\end{array}$ & $\begin{array}{c}\text { Density } \\
\left(\mathrm{g} / \mathrm{cm}^{3}\right)\end{array}$ & $\begin{array}{c}\text { Thermal } \\
\text { expansion } \\
\left(\mu \mathrm{m} / \mathrm{m}^{\circ}{ }^{\circ} \mathrm{C}\right)\end{array}$ & $\begin{array}{c}\text { Softening } \\
\mathrm{T}\left({ }^{\circ} \mathrm{C}\right)\end{array}$ \\
\hline E-glass & 3445 & 1080 & 2.58 & 5.4 & 846 \\
\hline
\end{tabular}

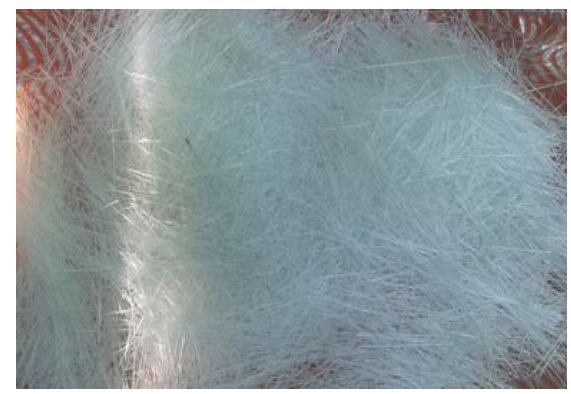

Figure 3: Glass fiber

\section{Experimental Work}

Mix design for each set having different combinations are carried out by using IS:10262 - 2009method. The mix proportion obtained for normal M25 grade concrete is $1: 1.87: 3.2$ with a water-cement ratio of 0.42 .

\section{Volume 5 Issue 6, June 2016 www.ijsr.net}




\section{International Journal of Science and Research (IJSR) \\ ISSN (Online): 2319-7064}

Index Copernicus Value (2013): 6.14 | Impact Factor (2015): 6.391

Table 8: Mix proportion

\begin{tabular}{|c|c|c|c|c|c|}
\hline Grade & $\begin{array}{c}\text { Cement } \\
\left(\mathrm{kg} / \mathrm{m}^{3}\right)\end{array}$ & $\begin{array}{c}\text { Fine } \\
\text { aggregate } \\
\left(\mathrm{kg}^{\mathrm{3}} \mathrm{m}^{3}\right)\end{array}$ & $\begin{array}{c}\text { Coarse } \\
\text { aggregate } \\
\left(\mathrm{kg} / \mathrm{m}^{3}\right)\end{array}$ & $\begin{array}{c}\text { Water } \\
(\text { Litres })\end{array}$ & $\begin{array}{c}\mathrm{W} / \mathrm{C} \mathrm{ratio} \\
\left(\mathrm{kg} / \mathrm{m}^{3}\right)\end{array}$ \\
\hline $\mathrm{M} 25$ & 364.9 & 685.3 & 1197.08 & 153.26 & 0.42 \\
\hline- & 1 & 1.87 & 3.2 & - & - \\
\hline
\end{tabular}

The experimental investigation consists of casting and testing of 9 sets along with control mix. Each set comprises of 18 cubes, 3 cylinders and 6 beams for determining compressive, tensile and flexural strengths respectively. By taking different percentage of GGBS, along with steel \& Glass fibers individually as a partial replacement of cement will be replaced accordingly with the different percentages by weight of slag and different percentages by weight of steel fiber and Glass fiber. The concrete was filled in layers and compacted. The specimens were removed after 24 hours and submerged in water for curing. After a curing period of 7 and 28 days specimens were taken out and tested.

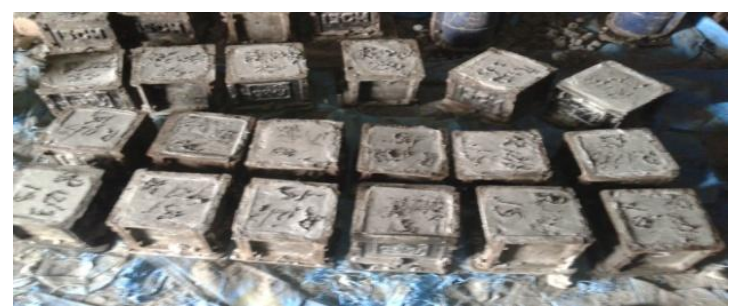

Figure 4(a): showing cubes compacted with concrete

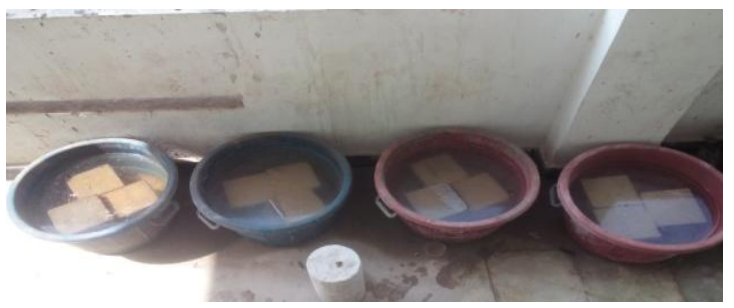

Figure 4(b): showing cubes in curing

\section{Tests and Results}

A number of tests were carried out to determine the design mix properties of concrete in the laboratory. In the present work, the strength of the hardened concrete is determined. The strength criterion includes measurement of following parameters:

- Compressive Strength on cubes

- Flexural Strength

- Split Tensile Strength on Cylinders

\subsection{Compression test}

Compression test on cubes of size $(150 \times 150 \times 150) \mathrm{mm}$ was performed on compression testing machine. Optimized Results of Trial Mixes are as shown in tables from the results of trial mix, it is seen that the compressive strength of Concrete for all percentage remains nearly same with replacement of cement by GGBS ,G.F and S F and found maximum for $20 \%, 1.5 \%$ and $0.2 \%$ slag, S.F \& G.F respectively replacement of cement. After testing the concrete (compressive strength) for M25 grade concrete separately for replacement of slag, steel and glass fiber by cement respectively finally combined percentage of slag \& steel fiber mix in which maximum strength is obtained was used to get optimized strength.

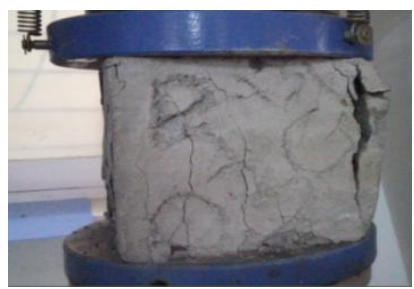

Figure 6: Compressive testing of cubes

\subsection{GGBS optimum percentages}

The mix proportions with partial replacement of OPC with $0 \%, 10 \%, 20 \%, 30 \%$ and $40 \%$ of GGBS are calculated.

Table 9: Compressive strength for steel fiber

\begin{tabular}{|c|c|c|c|}
\hline S. No & \% of & \multicolumn{2}{|c|}{ Compressive Strength $(\mathrm{MPa})$} \\
\cline { 3 - 4 } & GGBS & 7 days strength & 28 days strength \\
\hline 1 & 0 & 21.92 & 32.84 \\
\hline 2 & 10 & 22.81 & 34.23 \\
\hline 3 & 20 & 24.70 & 35.55 \\
\hline 4 & 30 & 23.01 & 34.18 \\
\hline 5 & 40 & 21.62 & 32.46 \\
\hline
\end{tabular}

From the test results, the optimum percentage replacement of GBBS was found to be $20 \%$. It is observed that the properties of can be maintained with GGBS as partial replacement of cement at $20 \%$.

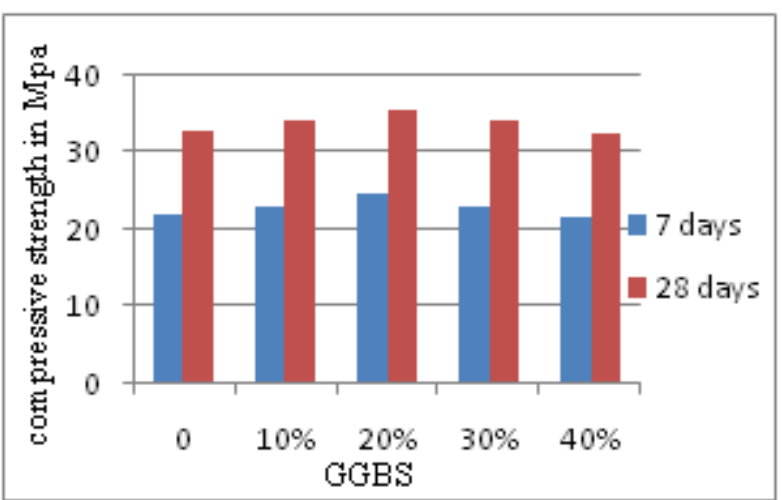

Graph 1: Compressive strength of GGBS for $7 \& 28$ days

Table 10: Compressive strength for steel fiber

\begin{tabular}{|c|c|c|c|c|}
\hline $\begin{array}{c}S l \\
. N o\end{array}$ & GGS \% & $\begin{array}{c}\% \text { Of } \\
\text { Steel fiber }\end{array}$ & $\begin{array}{c}7 \text { days } \\
\left(\mathrm{N} / \mathrm{mm}^{2}\right)\end{array}$ & $\begin{array}{c}28 \text { days } \\
\left(\mathrm{N} / \mathrm{mm}^{2}\right)\end{array}$ \\
\hline 1 & 20 & 0 & 21.92 & 32.88 \\
\hline 2 & 20 & 1 & 23.73 & 33.54 \\
\hline 3 & 20 & 1.5 & 25.56 & 33.96 \\
\hline 4 & 20 & 2 & 24.68 & 32.24 \\
\hline 5 & 20 & 2.5 & 23.72 & 31.43 \\
\hline
\end{tabular}




\section{International Journal of Science and Research (IJSR) \\ ISSN (Online): 2319-7064}

Index Copernicus Value (2013): 6.14 | Impact Factor (2015): 6.391

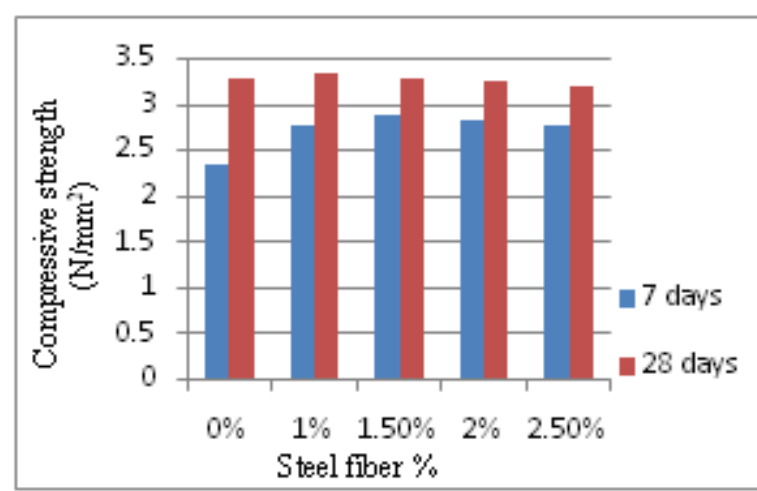

Graph 2: Compressive strength of steel fiber for $7 \& 28$ days

TABLE 11: Compressive strength for glass fiber

\begin{tabular}{|c|c|c|c|c|}
\hline S.No & $\begin{array}{c}\text { GGBS } \\
\%\end{array}$ & $\begin{array}{c}\% \text { Of } \\
\text { glass } \\
\text { fiber }\end{array}$ & $\begin{array}{c}7 \text { days } \\
(\mathrm{N} / \mathrm{m} \\
\left.\mathrm{m}^{2}\right)\end{array}$ & $\begin{array}{c}28 \text { days } \\
\left(\mathrm{N} / \mathrm{mm}^{2}\right)\end{array}$ \\
\hline 1 & 20 & 0 & 21.92 & 32.88 \\
\hline 2 & 20 & 0.1 & 23.43 & 33.42 \\
\hline 3 & 20 & 0.2 & 24.23 & 33.89 \\
\hline 4 & 20 & 0.3 & 24.48 & 32.12 \\
\hline 5 & 20 & 0.4 & 23.34 & 31.23 \\
\hline
\end{tabular}

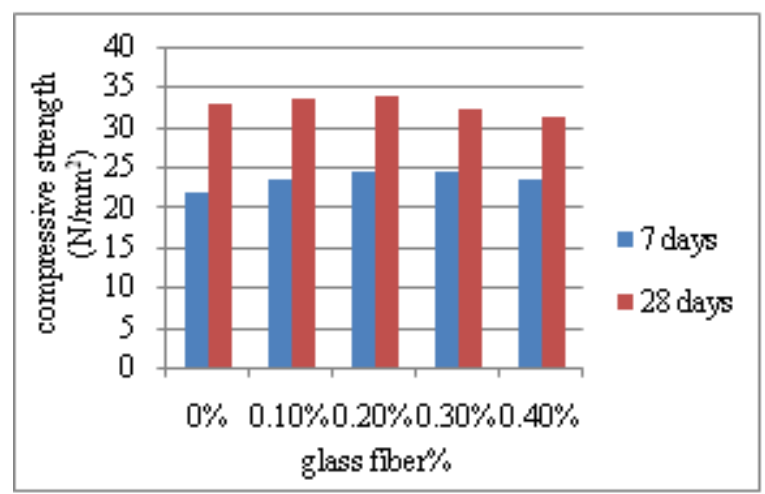

Graph 3: compressive strength for glass fibre for $7 \& 28$ days

\subsection{Flexural test}

Flexural test was performed on beams of $(500 \times 100 \times 100) \mathrm{mm}$ size by placing them on universal find out the flexural strength. After testing the concrete (flexural strength) for M25 grade concrete separately for replacement of slag, glass\& steel fiber by cement respectively finally combined percentage of slag \& steel fiber mix, slag \& glass fiber mix in which maximum strength is obtained was used to get optimized strength.

Table 12: Flexural test for steel fiber

\begin{tabular}{|c|c|c|c|c|}
\hline S.NO & $\begin{array}{c}\text { GGBS } \\
\%\end{array}$ & $\begin{array}{c}\% \text { OF STEEL } \\
\text { FIBER }\end{array}$ & $\begin{array}{c}7 \text { days } \\
\left(\mathrm{N} / \mathrm{mm}^{2}\right)\end{array}$ & $\begin{array}{c}28 \text { days } \\
\left(\mathrm{N} / \mathrm{mm}^{2}\right)\end{array}$ \\
\hline 1 & 20 & 0 & 3.27 & 4.01 \\
\hline 2 & 20 & 1 & 3.41 & 4.05 \\
\hline 3 & 20 & 1.5 & 3.54 & 4.08 \\
\hline 4 & 20 & 2 & 3.48 & 3.97 \\
\hline 5 & 20 & 2.5 & 3.41 & 3.92 \\
\hline
\end{tabular}

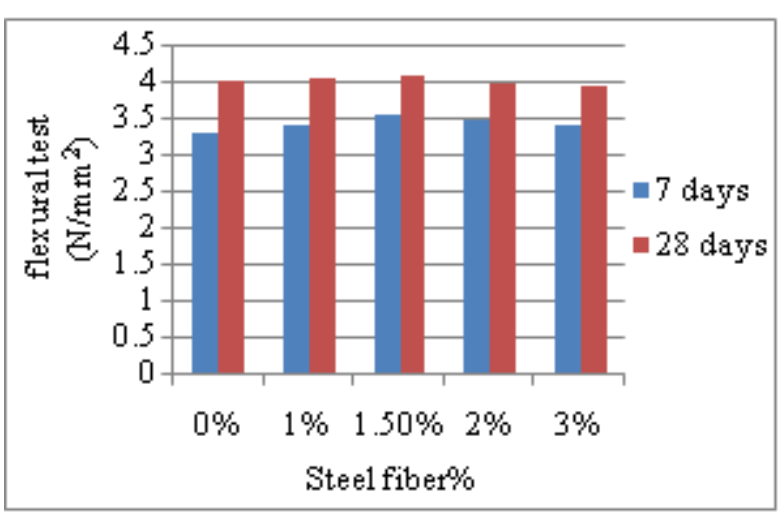

Graph 4: flexure test for steel fiber for $7 \& 28$ days

Table 13: Fleural test for glass fiber

\begin{tabular}{|c|c|c|c|c|}
\hline S.NO & $\begin{array}{c}G G B S \\
\%\end{array}$ & $\begin{array}{c}\% \text { OF GLASS } \\
\text { FIBER }\end{array}$ & $\begin{array}{c}7 \text { days } \\
\left(\text { N/mm }^{2}\right)\end{array}$ & $\begin{array}{c}28 \text { days } \\
\left(\text { N/mm }^{2}\right)\end{array}$ \\
\hline 1 & 20 & 0 & 3.27 & 4.01 \\
\hline 2 & 20 & 0.1 & 3.38 & 4.06 \\
\hline 3 & 20 & 0.2 & 3.44 & 4.07 \\
\hline 4 & 20 & 0.3 & 3.46 & 3.96 \\
\hline 5 & 20 & 0.4 & 3.38 & 3.91 \\
\hline
\end{tabular}

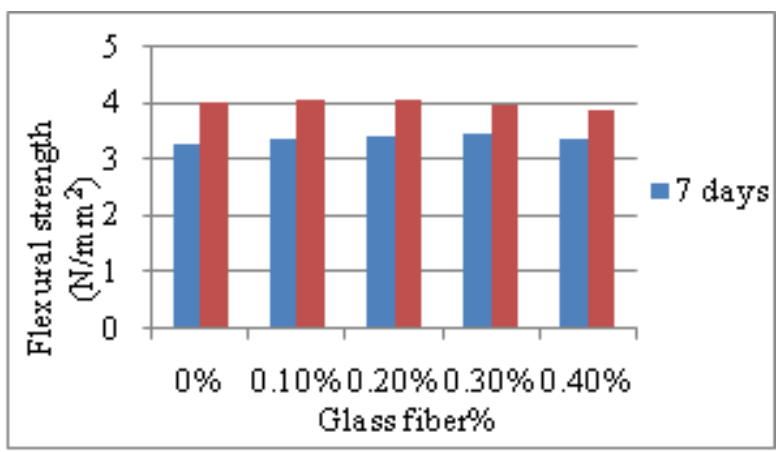

Graph 5: Flexural strength for $7 \& 28$ days

\subsection{Split Tensile Test}

Split tensile was performed on cylinders $150 \mathrm{~mm}$ dia. and $300 \mathrm{~mm}$ height on compression testing machine. The failure load was recorded to find out split tensile strength. After testing the concrete (split tensile strength) for M25 grade concrete separately for replacement of slag, glass \& steel fiber by cement respectively finally combined percentage of slag \& steel fiber mix, slag \& glass fiber mix in which maximum strength is obtained was used to get optimized strength.

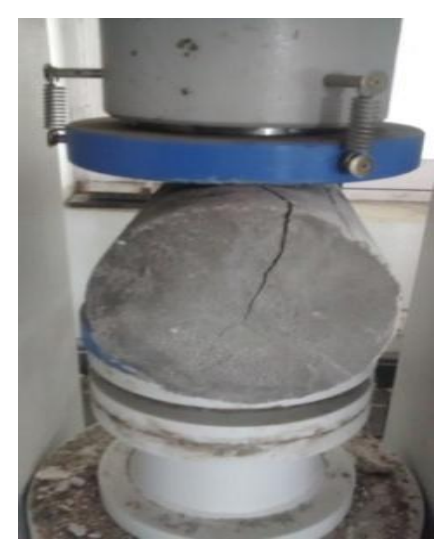

Figure 7: Tensile test on cylinders

\section{Volume 5 Issue 6, June 2016 www.ijsr.net}




\section{International Journal of Science and Research (IJSR) \\ ISSN (Online): 2319-7064}

Index Copernicus Value (2013): 6.14 | Impact Factor (2015): 6.391

Table 14: Split tensile test for steel fiber

\begin{tabular}{|c|c|c|c|c|}
\hline S.No & $\begin{array}{c}G G B S \\
\%\end{array}$ & $\begin{array}{c}\text { \% Of Steel } \\
\text { fiber }\end{array}$ & $\begin{array}{c}7 \text { days } \\
\left(\mathrm{N} / \mathrm{mm}^{2}\right)\end{array}$ & $\begin{array}{c}28 \text { days } \\
\left(\mathrm{N} / \mathrm{mm}^{2}\right)\end{array}$ \\
\hline 1 & 20 & 0 & 2.34 & 3.26 \\
\hline 2 & 20 & 1 & 2.77 & 3.33 \\
\hline 3 & 20 & 1.5 & 2.88 & 3.28 \\
\hline 4 & 20 & 2 & 2.83 & 3.23 \\
\hline 5 & 20 & 2.5 & 2.77 & 3.19 \\
\hline
\end{tabular}

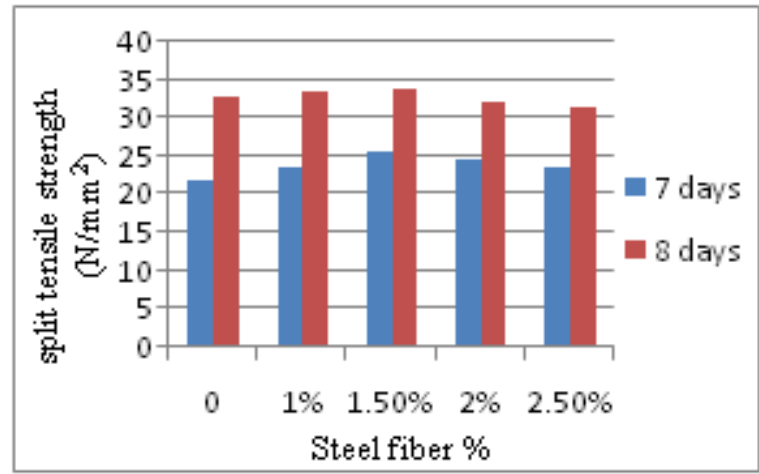

Graph 6: Split tensile test for steel fiber for $7 \& 28$ days

Table 15: Split tensile test for glass fiber

\begin{tabular}{|c|c|c|c|c|}
\hline $\begin{array}{c}\text { S. } \\
\text { No }\end{array}$ & $\begin{array}{c}\text { GGBS } \\
\%\end{array}$ & $\begin{array}{c}\text { \% Of Glass } \\
\text { fiber }\end{array}$ & $\begin{array}{c}7 \text { days } \\
\left({\left.\mathrm{N} / \mathrm{mm}^{2}\right)}^{2}\right)\end{array}$ & $\begin{array}{c}28 \text { days } \\
\left(\mathrm{N} / \mathrm{mm}^{2}\right)\end{array}$ \\
\hline 1 & 20 & 0 & 2.66 & 3.26 \\
\hline 2 & 20 & 0.1 & 2.75 & 3.28 \\
\hline 3 & 20 & 0.2 & 2.81 & 3.31 \\
\hline 4 & 20 & 0.3 & 2.82 & 3.23 \\
\hline 5 & 20 & 0.4 & 2.57 & 3.18 \\
\hline
\end{tabular}

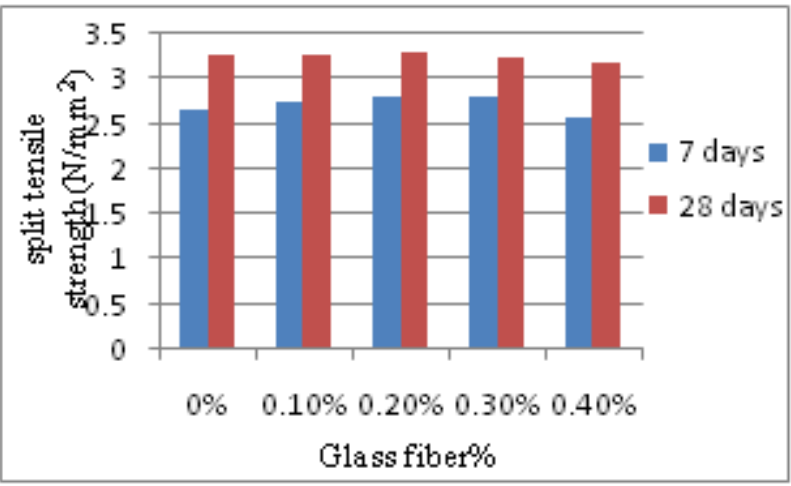

Graph 7: Split tensile strength for $7 \& 28$ days

\section{Conclusion}

- The optimum quantity for partial replacement of cement by ground granulated blast furnace slag is $20 \%$

- The optimum quantity for extension of steel fibred is $1.5 \%$

- The optimum quantity for extension of glass fiber is $0.2 \%$

- The percentage of increase in compressive strength for M25 grade for partial replacement of cement by GGBS $(20 \%)+$ extension of steel fibred $(1.5 \%)+$ +extension of glass fiber is $(0.2 \%)$ for $7 \& 28$ days of curing.

- The percentage of increase in flexural strength for M25 grade for partial replacement of cement by GGBS (20\%) + addition of steel fibred (1.5\%)+extension of glass fiber is( $0.2 \%$ ) for $7 \& 28$ days of curing.

- The percentage of increase in split tensile strength for M25 grade for partial replacement of cement by GGBS
$(20 \%)+$ addition of steel fibred $(1.5 \%)$ +extension of glass fiber is $(0.2 \%)$ for $7 \& 28$ days of curing.

- Test results display that higher fiber content has conduct around increased compressive strength, flexural strength, abrasion resistance, and fiber crack-control effect. Hence the addition of steel\& glass fiber within FRC is more helpful for the flexural strength than the compressive strength.

\section{References}

[1] Santosh Kumar Karri, G.V.Rama Rao, P.Markandeya Raju, "The Strength and Durability Studies on GGBS Concrete", volume 2, Issue 10, October 2015.

[2] Arvind B. Nakum, Vatsal N patel,vishal B. patel "Experimental study on mechanical and durability properties of high strength concrete incorporating ggbs and steel fibers", International journal of engineering research, volume 3, Issue 4, 2015.

[3] 3. Avinash gornale, S Ibrahim quadri, Mehmood Quadri, Syed Md Akram Ali, Syed Shamsuddin Hussaini, "Strength Aspects of Glass Fibre Reinforced Concrete", volume 3, issue 7, July -2012.

[4] D.Neeraja, "Experimental investigations on strength characteristics of steel fibre reinforced concrete", volume 2, issue 7, 2014.

[5] A.M.Shende, A.M. Pande, M.Gulfam Pathan, "Experimental study on steel fiber reinforced concrete for M-40 grade", volume 4, issue 2, February-2013.

[6] IS 10262:2009, "Concrete mix proportioning Guidelines".

[7] IS 456:2000, "Plain and reinforced concrete- code of practise". 